原著論文

\author{
撮影画像の明度コントラストが感性的評価に及ぼす影響 \\ 石川 智治*, 陳 怡君*, 白川 俊之*, 江田 哲也**, 小黒 久史 ${ }^{*}, * *$, 郭 素梅****, \\ 佐藤 美恵*, 春日 正男*, 阿山 みよし* \\ * 宇都宮大学大学院工学研究科, ${ }^{* *}$ 宇都宮大学オプティクス教育研究センター, ${ }^{* * *}$ 凸版印刷株式会社, ${ }^{* * * *}$ 北京理工大学珠海学院
}

\title{
Influence of Lightness Contrast on KANSEI Evaluation of Photographic Images
}

Tomoharu ISHIKAWA*, Yi-Chun CHEN*, Toshiyuki SHIRAKAWA*, Tetsuya EDA**, Hisashi OGURO*,***, Sumei GUO****, Mie SATO*, Masao KASUGA* and Miyoshi AYAMA*

* Graduate School of Engineering, Utsunomiya University, 7-1-2 Yoto, Utsunomiya, Tochigi 321-8585, Japan ** Center for Optical Research and Education, Utsunomiya University, 7-1-2 Yoto, Utsunomiya, Tochigi 321-8585, Japan *** TOPPAN PRINTING Co.,Ltd, 1-3-3 Suido, Bunkyo, Tokyo 112-8531, Japan

**** Beijing Institute of Technology, Jinfeng Road, Tangjiawan, Zhuhai, Guangdong, 519085, P.R.China

\begin{abstract}
The purpose of this study is to clarify the effects of the lightness of main objects $\left(L_{t}\right)$, background $\left(L_{b}\right)$, and the lightness contrasts $\left(\left|L_{t}-L_{b}\right| / L_{a v}\right)$, upon observers' KANSEI impression, and further to investigate their relation to the screen size. In this experiment, 17 pictures with different lightness contrasts were taken by the digital camera. 68 test images are prepared by converting each of the original pictures to four different sizes. A test image was presented on a display to the observer, and he/she was instructed to evaluate the impression of the image using an index with seven ranks ranging from 0 to 6 for 22 assessment words. Results showed that subjective rating value for psychophysical properties of image increases monotonously with the increase or decrease of the lightness contrast, respectively. On the other hand, the rating value for KANSEI impression of image showed a peak at moderate contrast. Effect of image size was significant for the larger the image size. Results of multiple classification analysis on all subjective rating values indicated that "KANSEI factor" is strongly related to the lightness of main object and the image size.
\end{abstract}

Keywords : KANSEI evaluation, Photography, Lightness contrast, Image size, Multiple classification analysis

\section{1.は じめに}

近年，ネットワーク技術の進歩により，誰でも何処でも携 帯電話や端末機器等からの必要な情報の入手や, オンデマン ドでの様々なコンテンツの視聴が可能となってきた．特に, ネットビジネスは急速に成長し, 写真画像や書き込み情報か ら判断して商品を購入するネットショッピングが盛んになっ てきている [1]. 一方で, 実際の商品の素材感や質感等が 必ずしもイメージと一致しないという問題が生じている。 そ の原因としては, 送り手の意図（コンセプト）が, 撮影した 画像情報に盛り込めていない場合, 或いは, 送り手の意図を 受け手が感じ取れるような画像表示となっていない場合，ま たは，その両方が考えられる，送り手の具体的な問題として は, コンテンツ商品の質感や䨌囲気等を表現するための照明 条件やそれらを撮影するためのカメラの設定条件等が明らか になっていないことが挙げられる。 また，受け手の具体的な 問題としては, 携帯電話等の小画面からスーパーハイビジョ ン等の大画面に至るまでの多種多様なディスプレイが存在し ているにも関わらず，それらに適応した表示技術が確立され ていないことが挙げられる。したがって, 異なる画面サイズ において, 可能な限り等価的な感性的価值を受け手が得られ るようにするためには, 撮影変動要素と画面サイズとの関係 の基礎的な検討が必要である [2-5].
我々は先行研究 [6] において,「果実」,「花」,「建物」 の3 種の画像を用い，ピクセル毎に明度及び彩度コントラス 卜を変換させ，3種類の画像サイズで提示して，感性的評価 を行った。 その結果, 感性的評価が高くなる適切な明度及び 彩度コントラストが存在すること，また全体的に画像サイズ が大きい場合には肯定的評価語の評価は高く，否定的評価語 の評価は低いことが明らかになった。一方，画像サイズが小 さい場合には，彩度コントラストを強調する方が良いことが 明らかになった。さらに, 被験者が画像全体の明るさを判断 する時は, 平均明度ではなく, オブジェクトの明度が重要と なる可能性が示唆された。

そこで本研究では, オブジェクトと背景の明るさに注目し た撮影を行い, その画像を異なるサイズに変換して人間の感 性的視点から評価・検討する。そして, 異なる撮影条件や表 示環境において可能な限り等価的な感性的価值を与えうる画 像提示手法の確立を目指す。具体的には，まずオブジェクト と背景の照明条件を変化させ，画像内のオブジェクトと背景 の明度コントラストが異なる画像を撮影する。次に, 撮影し た各画像を異なるサイズに変換処理した画像を作成する。こ れらの作成画像を使用し，2種類の視距離から感性的評価実 験を行い, その結果から異なる画像サイズにおいて, オブジェ クトと背景の明度コントラストが感性的評価にどのように影 響するのかを検討する。 


\section{2. 感性評価実験}

\section{1 評価 画 像}

\subsection{1 評価画像の撮影}

まず，オブジェクトは撮影条件の変更に伴う時間の影響を 受けない，すなわち，それ自体が時間的に変化しないこと， 及び被験者の趣味的な嗜好が評価に影響を及ぼさないこと等 を考慮して, 高品質な果物の模型（図1（a））とした。厳密 には，籠を含む果物模型を“オブジェクト”とした。また， “背景”は出来る限り一様な無彩色となるようにした.

次に，オブジェクトと背景の明度コントラストが異なる画 像を照明条件の相違だけで実現することとした。ネット ショッピング用の画像等への応用を考慮し, 画像処理による 明度コントラストの調整を避けたかったからである。オブ ジェクトの明るさを変化させるための前方照明と背景の明る さを変化させるための後方照明を段階的に調整できる照明 セットを準備した（図2）。具体的には, 後方照明は一定に 保ちながら前方照明と拡散板 (乳白板) との距離を 10段階 (約 $10 \mathrm{~cm}$ 間隔）に変化させることにより, 背景輝度が一定で, オブジェクト輝度を変化させた 11 種の条件において撮影し た。 また, 前方照明は固定し, 後方照明にNDフィルタ（濃 度 $25 \%$ 及び $50 \%$ の組み合わせ）を用いて6段階で輝度を調 整することにより，オブジェクト輝度が一定で, 背景輝度を 変化させた 7 種の条件で撮影した。 その結果, 撮影画像は合 計 17 枚とした。 また撮影は暗室にて行い, ディジタルカメ ラ（Nikon社製D50）を用いて, 焦点距離：38 mm, ISO感 度 : 200, シャッタースピード : 2 秒, 解像度 : $3008 \times 2000$ pixel 等で撮影した。明るさ調整用の前方・後方照明には市 販の昼白色 3 波長発光形蛍光灯 (相関色温度 $5000 \mathrm{~K}$ ) を用い, 後方照明とオブジェクトとの間には無地のトレーシングペー パーを設置した。

\section{1 .2 評価画像の明度コントラスト}

撮影画像の特性として，オブジェクトと背景の明度コント ラストを算出した。まず画素毎の明度を求め, 次に撮影画像 内からオブジェクトのみを抽出した領域内の平均明度をオブ ジェクト明度 $\left(L_{t}\right)$ とし, その領域以外の平均明度を背景明 度 $\left(L_{b}\right)$ とする。 そしてオブジェクト明度と背景明度の差の 絶対值を, 画像全体の平均明度 $\left(L_{a v}\right)$ で割った值 $\left(\left|L_{t}-L_{b}\right| / L_{a v}\right)$ を明度コントラストとして採用した。

画素毎の明度は, sRGBにより $R G B$ 值を $X Y Z$ 值に変換し, D65 光源下の完全拡散反射面を基準白色 $\left(X_{n}=0.9504, Y_{n}=\right.$ $1.0000, Z_{n}=1.0888 ）$ として算出した $L^{*} a^{*} b^{*}$ 值の $L^{*}$ 值とす る. 図1（b),（c）のように, 画像全体においてオブジェク 卜領域と背景領域を分離した。具体的には，撮影画像中の才 ブジェクト（果物＋籠）の部分を手作業で抜き出した領域を オブジェクト領域とし，それ以外の領域を背景領域とした。 撮影画像 17 種類（1)～17) に対するオブジェクトと背景の 明度, 及び明度コントラストを表1に示す。

表1より, 撮影画像1)～(11)（これ以降, オブジェクト明度
変化画像群と呼ぶ) は背景明度が約 94 とほぼ一定で(平均值： 94.1, 標準偏差 : 0.53), オブジェクト明度が単調増加する ことにより, 明度コントラストが単調減少する画像群であ る。これに対し，撮影画像(8)，(12)（17)（これ以降，背景明度 変化画像群と呼ぶ）はオブジェクト明度が約 34 とほぼ一定 で (平均值 : 34.0, 標準偏差 : 1.74), 背景明度が単調減少 することにより，明度コントラストが単調減少（撮影画像16 から17にかけてのみ増加）する画像群である，以上より，照 明条件が異なる撮影から明度コントラストが変化する全 17 枚の画像群を作成した。図3に横軸を背景明度 $\left(L_{b}\right)$, 縦軸 をオブジェクト明度 $\left(L_{t}\right)$ とする撮影画像群を示す.

\subsection{3 実験用評価画像の作成}

画面サイズ以外の変動要因を排除した評価実験を実施する ために，同一ディスプレイにて異なる画像サイズのコンテン ツを表示した。このために, 撮影画像をサイズの異なる4種 に変換した。本実験において使用する画像提示用ディスプレ イは, SHARP AQUOS LC-65RX1W（65型）であり，画面 中央部に各画像を 4 種類のサイズ（対角約 7inch, 14inch,

29inch，57inch）で提示した. 画像表示は57inchでは撮影 画像のまま，他のサイズでは線形変換により縮小して，各サ イズの余㮃領域にグレー（N5）を表示した。なお，縮小の 繰り返し処理は対角約29inchでは 1 回, 14inchでは 2 回, 7 inchでは 3 回行った。 以上より, 撮影画像 17 種に対し 4 種 のサイズ変換を行った計68枚の評価画像を作成した。

\section{2 評 価 実 験 \\ 2.2.1 評価環境と評価手順}

評価実験室は, 外光や周囲の色彩の影響を低減するため に, 壁面やデイスプレイ以外の部分をグレー (N5 相当)のカー

表 1 オブジェクト明度, 背景明度, 明度コントラスト

\begin{tabular}{|c|c|c|c|}
\hline $\begin{array}{c}\text { 撮影 } \\
\text { 画像 }\end{array}$ & $\begin{array}{c}\text { オブジェクト } \\
\text { 明度 }\left(L_{t}\right)\end{array}$ & $\begin{array}{c}\text { 背景明度 } \\
\left(L_{b}\right)\end{array}$ & $\begin{array}{c}\text { 明度コントラスト } \\
\left(\left|L_{t}-L_{b}\right| / L_{a v}\right)\end{array}$ \\
\hline (1) & 2.74 & 93.65 & 1.81 \\
\hline (2) & 11.69 & 94.02 & 1.54 \\
\hline (3) & 14.39 & 93.78 & 1.47 \\
\hline (4) & 14.69 & 94.10 & 1.42 \\
\hline (5) & 22.25 & 93.00 & 1.23 \\
\hline (6) & 27.40 & 94.24 & 1.10 \\
\hline (7) & 30.46 & 94.28 & 1.03 \\
\hline (8) & 35.81 & 94.41 & 0.90 \\
\hline (9) & 41.43 & 94.65 & 0.78 \\
\hline (10) & 47.13 & 94.86 & 0.67 \\
\hline (11) & 51.67 & 94.94 & 0.59 \\
\hline (12) & 36.46 & 84.71 & 0.81 \\
\hline (13) & 31.52 & 71.94 & 0.77 \\
\hline (14) & 33.81 & 57.45 & 0.52 \\
\hline (15) & 34.65 & 47.26 & 0.32 \\
\hline (16) & 33.53 & 37.23 & 0.11 \\
\hline (1) & 32.60 & 23.26 & 0.34 \\
\hline
\end{tabular}


テンで覆った．環境照明は実験室に備え付けの蛍光灯をその まま用いた。ディスプレイ中央付近の水平面照度は約 285 $1 \mathrm{x}$, 鉛直面照度は約 350 lx である. 被験者は実験室へ入室後, 3 分間明順応してから評価を開始する。画像 1 枚の評価時間 は被験者の任意とした。また，画像間の比較評価を避けるた め, 次の画像の提示前に灰色画像（N5 相当）を5 秒間表示 した.

全ての画像とサイズの組合せは 68 条件であるが, 被験者 の負担を考慮して4セッションに分け, 各セッションの試行 回数を 17 回とした. 更に, 視距離を 2 条件（ディスプレイ 正面から $160 \mathrm{~cm}$ と $320 \mathrm{~cm}$ ：ディスプレイ高さ $(\mathrm{H})$ が約 $80 \mathrm{~cm}$ であるため $2 \mathrm{H}$ と $4 \mathrm{H}$ に相当）として，4セッションず

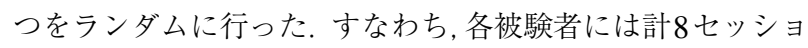
ン, 136 試行の評価実験を課した.

以上の実験フローを図4に示す。被験者は色覚正常者 (C型色覚)の 20 歳〜25歳の男性及び女性の計 15 名とした.

\subsection{2 評価語と評価方法}

評価項目は, 先行研究 [6] で用いた22語の評価語（表2） とした，評価尺度は，「感じない（0 点)」「少し（2点)」「はっ きり (4 点)」「非常に (6 点)」とする単極 SD 法7段階評価 を用いた，各画像に対する評価シートは，評価項目毎の順序 効果を避けるために評価項目がランダムに記載されるように した。

\section{3. 評価実験結果と考察}

\section{1 明度コントラスト及び画像サイズの影響}

評価項目毎に 15 名の被験者の評価得点の平均值を求め, 明度コントラスト及び画像サイズとの関係を調べた。その結 果, 特徵的な傾向を示した「明るい」と「暗い」,「明暗が強い」 と「明暗が弱い」,「立体的な」と「平面的な」,「美味しそうな」 と「不味そうな」をそれぞれ図5～図8に, 各々左側にオブジェ クト明度変化画像群及び右側に背景明度変化画像群に分けて 示す。なお，評価得点と明度コントラストとの関係は視距離 $(160 \mathrm{~cm}$ と $320 \mathrm{~cm})$ が違う場合でも，ほぼ同様の傾向を示し たので $320 \mathrm{~cm}$ の場合のみ示す（なお，撮影画像17)（明度コン トラスト 0.34）の評価点は, 図の見易さからプロットのみで 示す). また, 得られた評価得点の結果に対して, 明度コン トラストと画像サイズを要因とする二元配置分散分析を行っ たので，以下ではそれについても述べる.

まず図5（a）（c）より，オブジェクト明度変化画像群の

表2 評価項目

\begin{tabular}{|c|c|c|c|}
\hline 明暗が弱い & 明暗が強い & 色が薄い & 色が濃い \\
\hline 暗い & 明るい & 平凡な & 印象的な \\
\hline ぼんやりした & はっきりした & 地味な & 派手な \\
\hline 不自然な & 自然な & 污い & きれいな \\
\hline 嫌い & 好き & 不味そうな & 美味しそうな \\
\hline 平面的な & 立体的な & & \\
\hline
\end{tabular}

評価得点は明度コントラスト増加に伴い,「明るい」では単 調減少し, 逆に「暗い」では単調増加する。一方, 図5（b） （d）より, 背景明度変化画像群の評価得点は, 明度コント ラスト増加に伴い,「明るい」・「暗い」はやや単調増加・減 少の傾向にあるが, その増減量はオブジェクト明度変化画像 群の場合に比して少ない。また分散分析の結果, オブジェク 卜明度変化画像群 · 背景明度変化画像群共に明度コントラス トの影響は有意であるが $(\rho<0.01)$ ，画像サイズ間の有意差 は見られなかった。すなわち，「明るい」や「暗い」の評価 得点は，オブジェクトと背景の明度コントラストに強い影響 を受けるが，画像サイズには影響を受けないことが明らかに なった。また「明るい」や「暗い」において，被験者は背景 明度の変化ではなく，オブジェクト明度の変化から判断して 「明るい」や「暗い」を評価していると考えられる。

次に図6（a）（c）より，オブジェクト明度変化画像群の 評価得点は明度コントラスト増加に伴い,「明暗が強い」で はやや単調増加傾向にあるものの，「明るい」や「暗い」等 に比して減少量は少なく，「明暗が弱い」に至っては殆ど変 化が無い. 図6（b）（d）より，背景明度変化画像群の評価 得点は明度コントラストの変化に対して影響を受けない。分 散分析の結果,「明暗が強い」及び「明暗が弱い」の評価得 点において，オブジェクト明度変化画像群では明度コントラ ストの影響は有意 $(\rho<0.01)$ であったが, 背景明度変化画 像群では有意差はなかった。またオブジェクト明度変化画像 群・背景明度変化画像群共に画像サイズ間の有意差は見られ なかった。以上より,被験者は「明暗が強い」「明暗が弱い」 については，オブジェクトと背景の明度コントラストだけに 基づいて判断しているのではなく，画像全体の明暗のバラン スによる判断をしている可能性がある。 また, 意味的にペア となる評価語の評価得点の結果が対称性を持つとは限らない ことも明らかになった。このことは, 郭らの単極評価法に関 する先行研究 [7] と同様の結果である。

次に図7（a）（c）より, オブジェクト明度変化画像群の 評価得点は明度コントラスト増加に伴い,「立体的な」では 若干なだらかな単調減少傾向にあるものの,「平面的な」で はあまり変化がないといえる。この傾向は, 図7 (b) (d) の背景明度変化画像群の評価得点においても同様である。分 散分析の結果, オブジェクト明度変化画像群では明度コント ラストの影響は有意 $(\rho<0.01)$ であったが，背景明度変化 画像群では有意差はなかった。これに対し, 図7 (a)〜 (d) の全てにおいて，画像サイズによる評価得点の増減が見られ る.「立体的な」の評価結果である図7 (a)（b）では，画像 サイズが大きくなるにつれて評価得点は増大し,「平面的な」 の評価結果である図7 (c) (d) では, 画像サイズが小さく なるにつれて評価得点が増大している。分散分析の結果, 才 ブジェクト明度変化画像群・背景明度変化画像群共に画像サ イズの影響は顕著に有意であった $(\rho<0.01)$ ，以上より，「立 体的な」や「平面的な」の評価得点は，画像サイズには強い 影響を受けるが，明度コントラストには殆ど影響を受けない ことが明らかになった。すなわち, 被験者は「立体的な」「平 


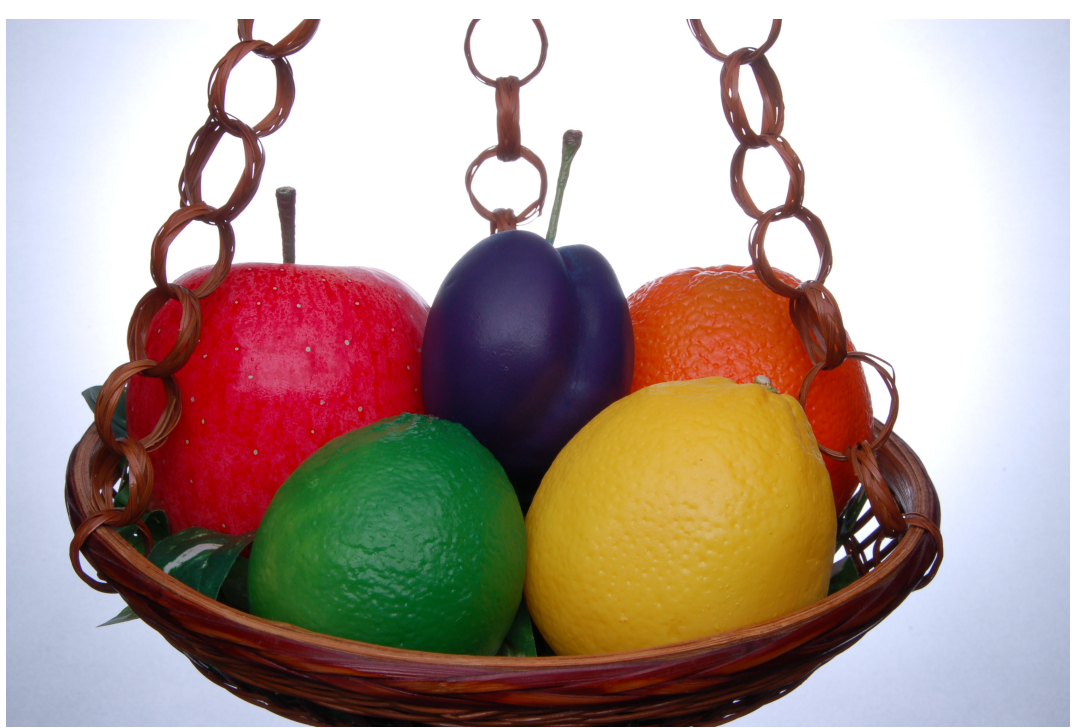

(a) 撮影画像全体

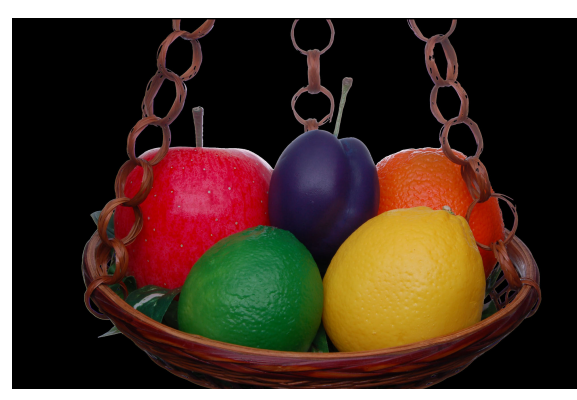

（b）オブジェクト領域（領域以外は黒色）

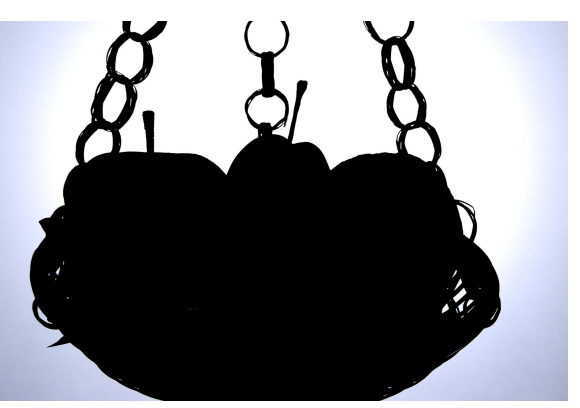

（c）背景領域（領域以外は黒色）

図1 撮影画像及びオブジェクト領域と背景領域

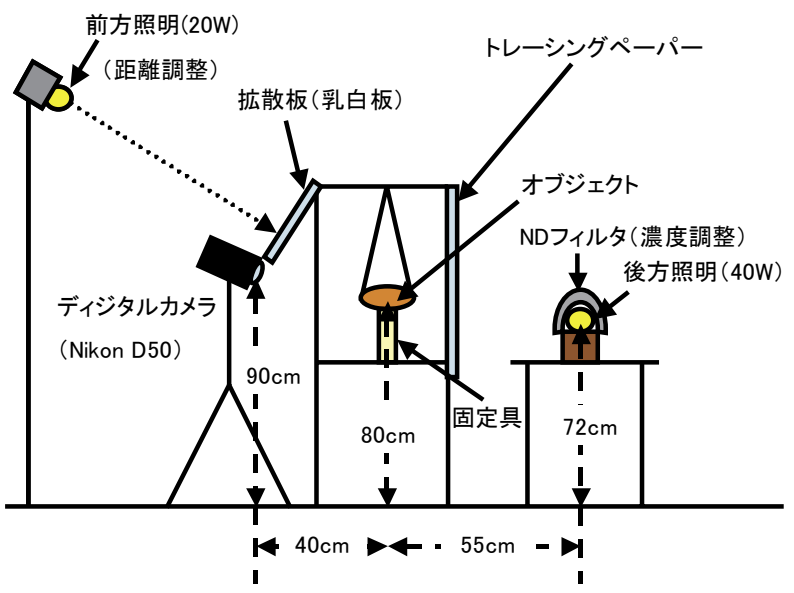

図2 撮影環境

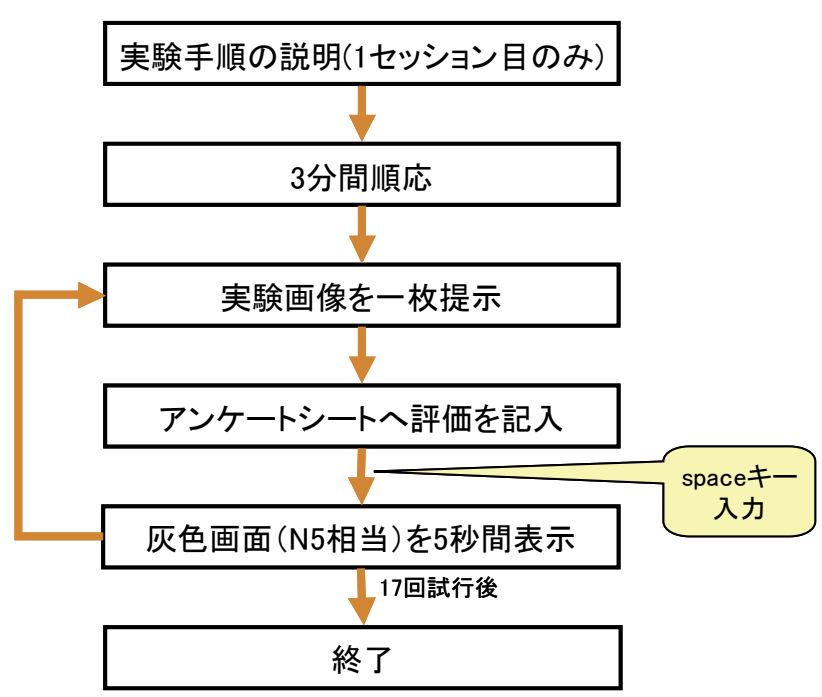

図4 実験フロー

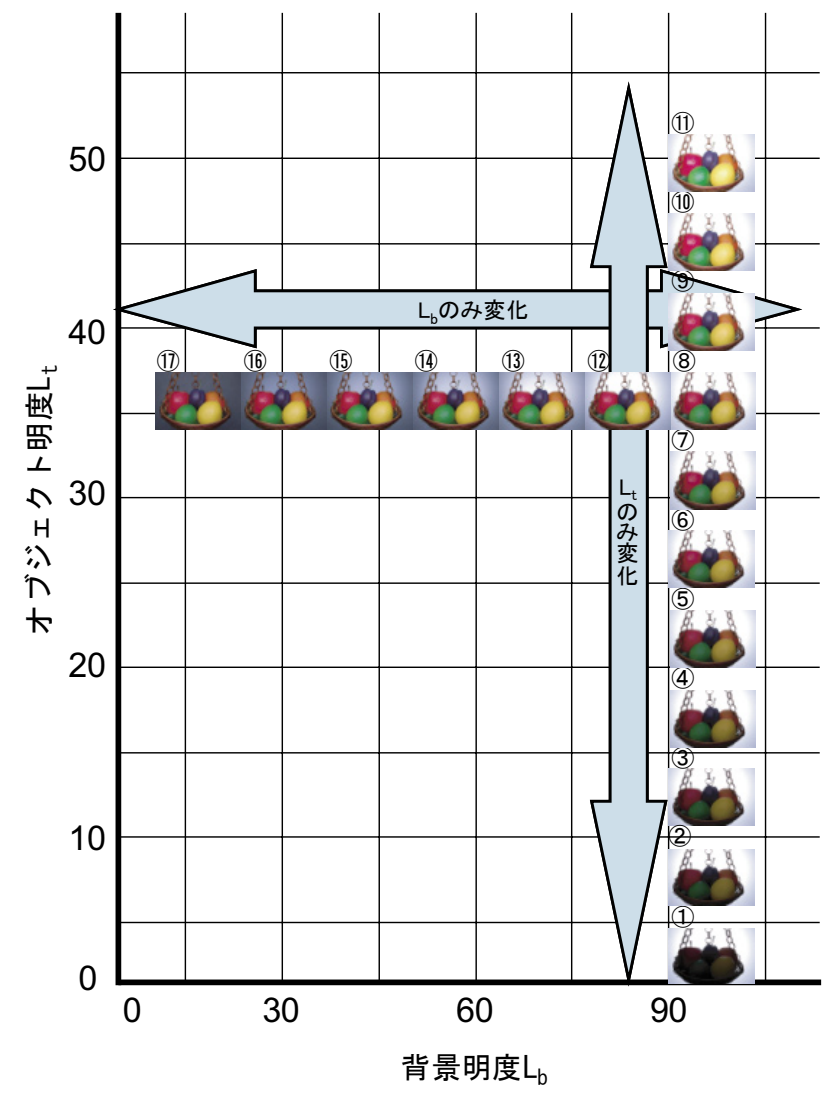

図3撮影画像群

面的な」について，オブジェクトと背景の明度コントラスト ではなく，主として画像サイズから判断して評価しているこ とが示唆される

図8（a）より, オブジェクト明度変化画像群の評価得点 は明度コントラスト増加に伴い,「美味しそうな」では, 明 度コントラストが 0.78 (約 0.8 ) 付近で最大值を持つ傾向に 

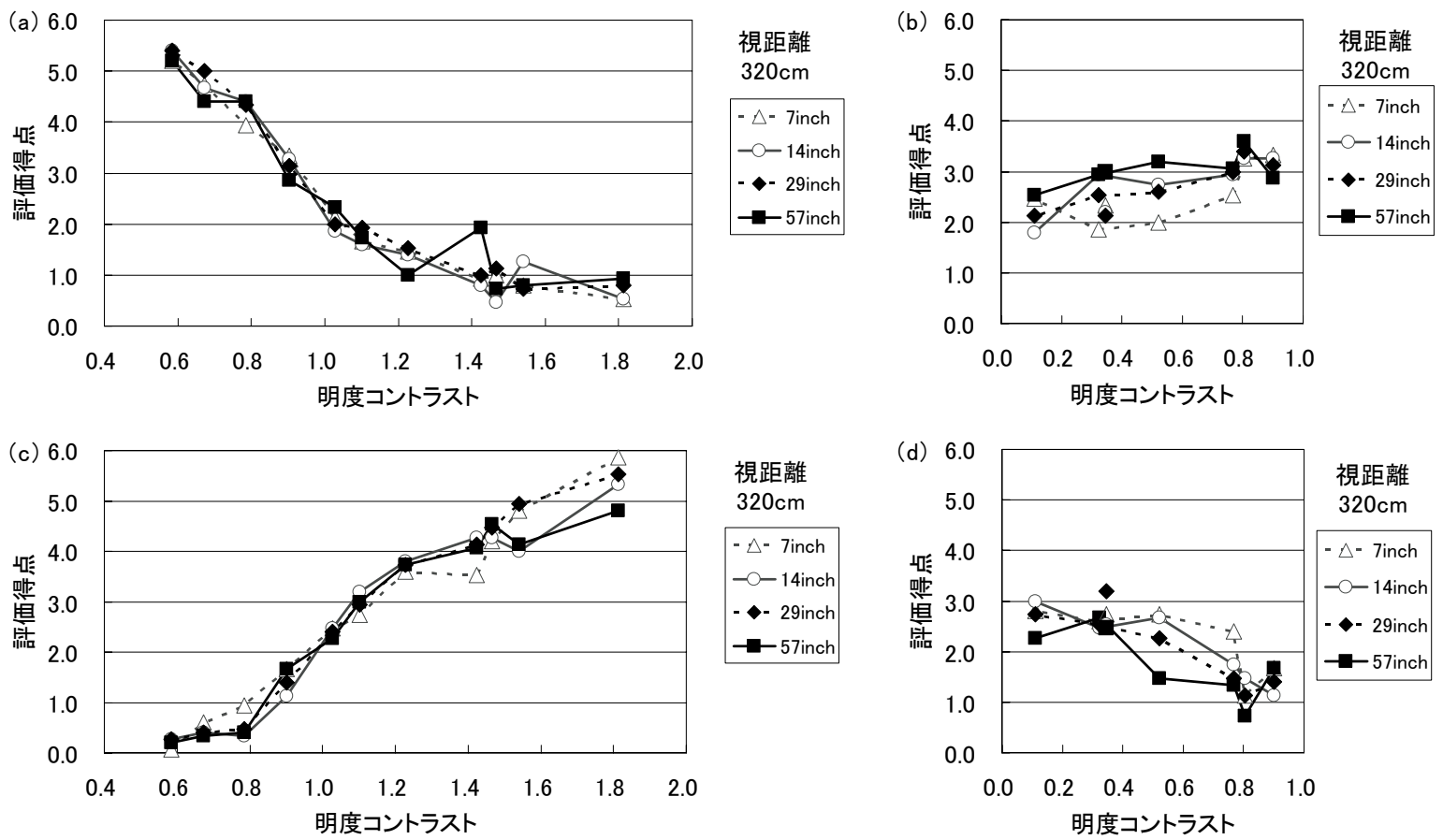

オブジェクト明度変化画像群

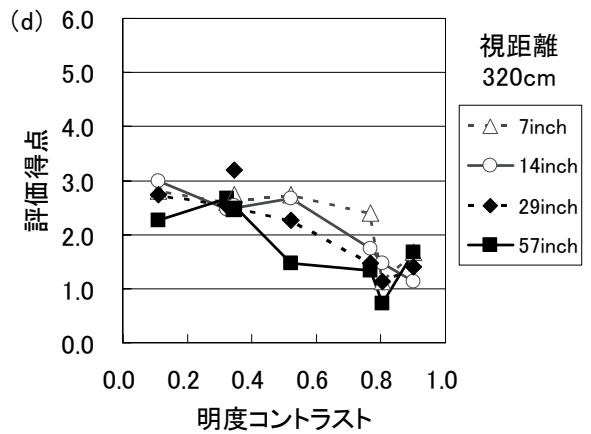

図5 評価得点と明度コントラストの関係（上：明るい, 下：暗い）
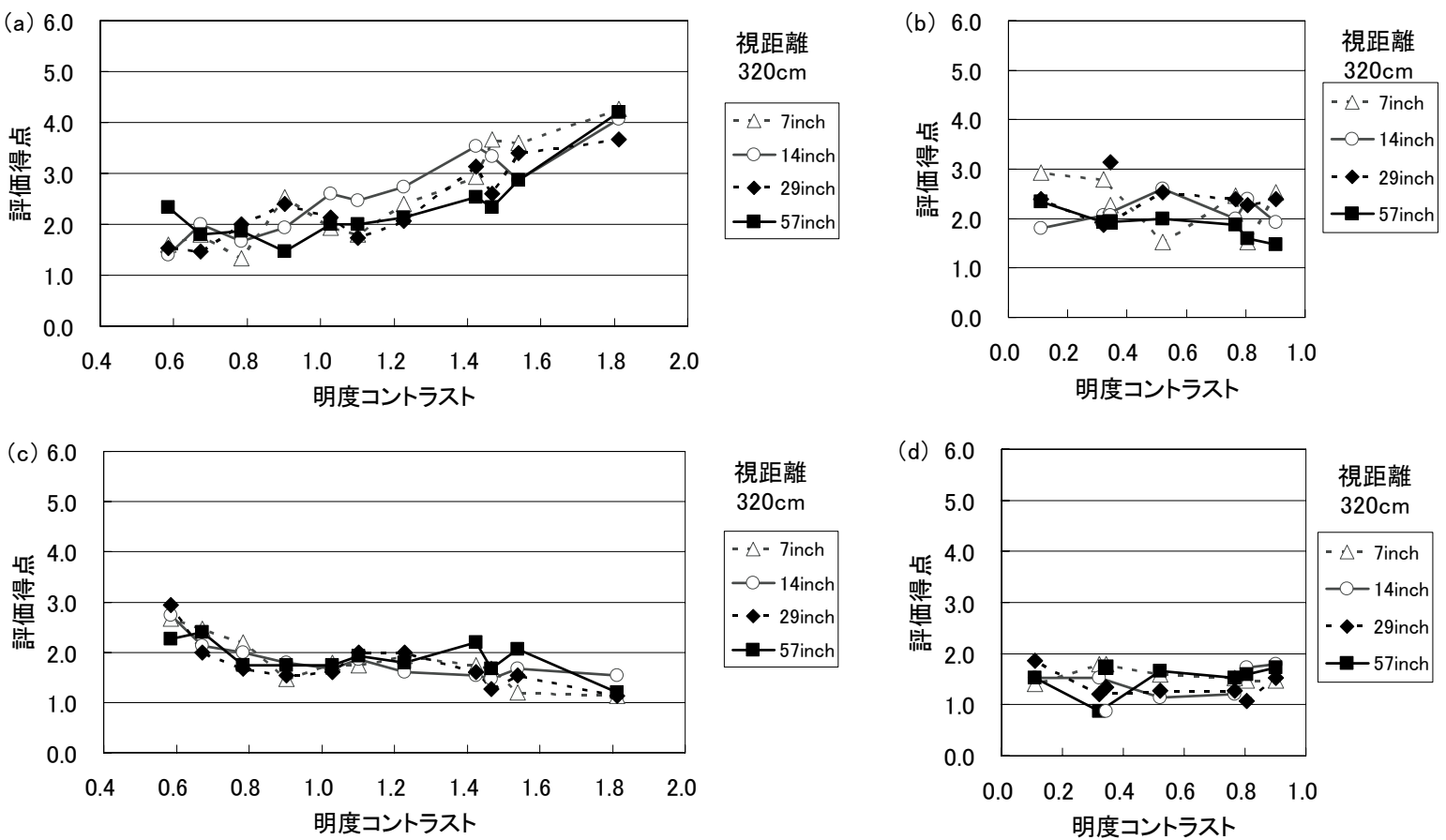

オブジェクト明度変化画像群

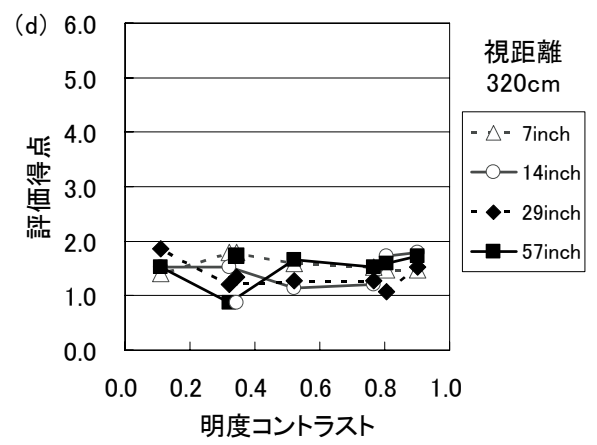

背景明度変化画像群

図6 評価得点と明度コントラストの関係（上：明暗が強い, 下：明暗が弱い）

ある，逆に，図8（c）の「不味そうな」では，明度コント ラストが約 0.8 付近で最小值を持つ傾向にある。また画像开 イズが大きい方が「美味しそうな」では高得点「「不味そうな」 では低得点という傾向が見られる。分散分析の結果，「美味 しそうな」と「不味そうな」の評価得点において, 明度コン トラスト及び画像サイズの影響は共に有意であった $(\rho<0.01)$. 一方, 図8（b）（d）ょり, 背景明度変化画像群
の評価得点は明度コントラスト増加に伴う系統的変化は見ら れないが，画像サイズに関しては図8（a）と同様な変化が 見られる。分散分析の結果,「美味しそうな」と「不味そうな」 の評価得点において，明度コントラスト及び画像サイズの影 響は共に有意であった $(\rho<0.01)$ ．以上より，「美味しそうな」 「不味そうな」の評価得点は, 特にオブジェクト明度変化画 像群において，明度コントラストに強く影響を受け，同時に 

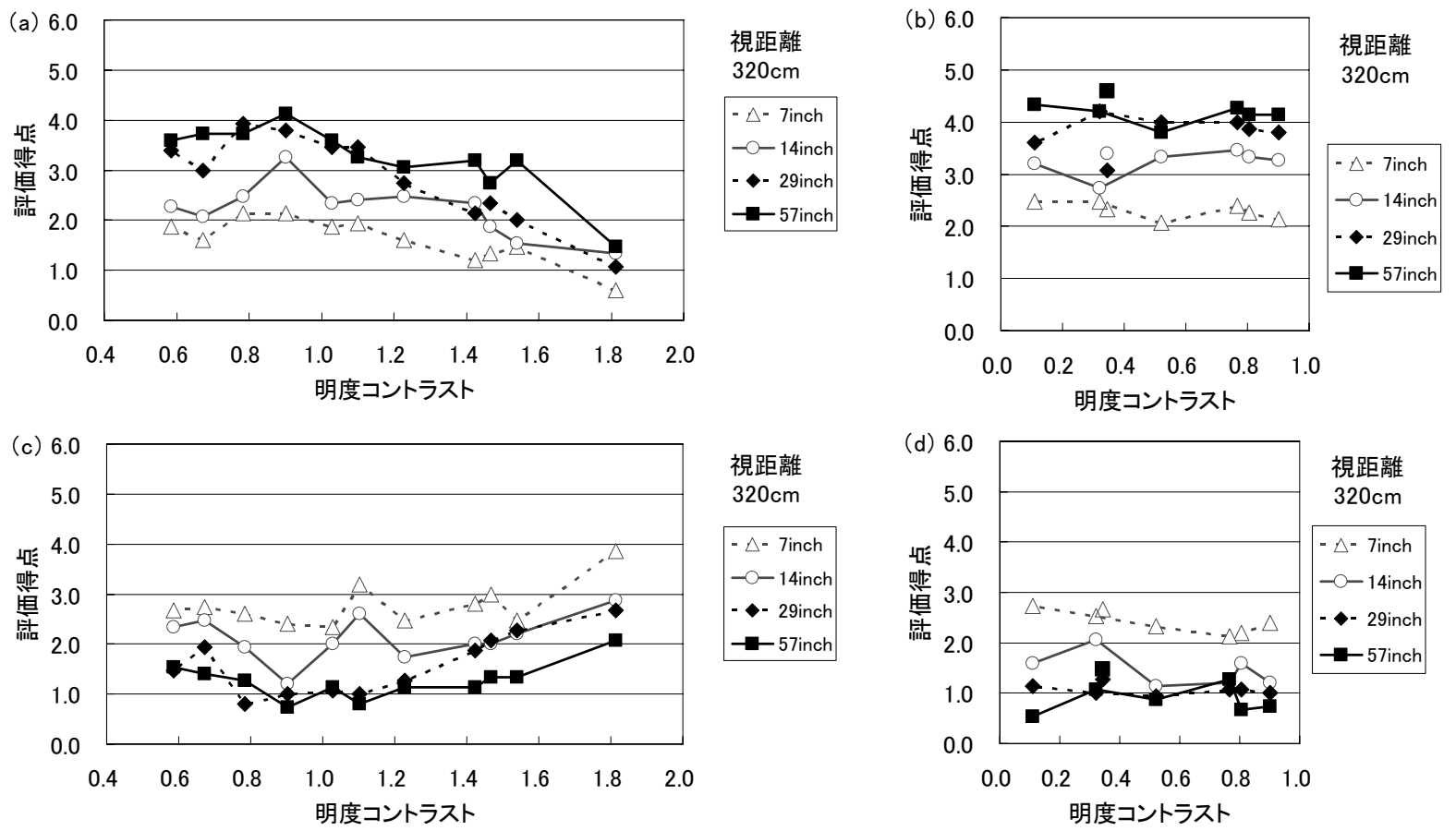

オブジェクト明度変化画像群

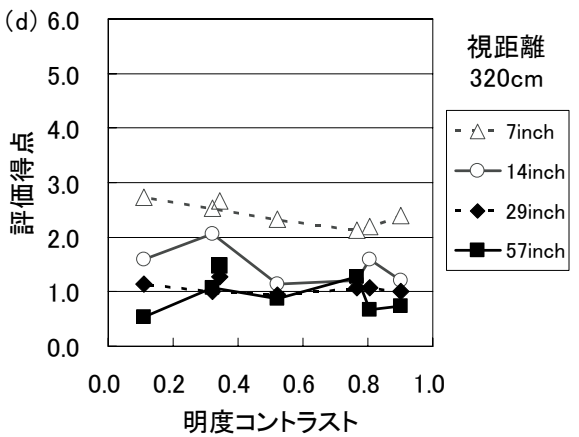

図 7 評価得点と明度コントラストの関係（上：立体的な,下：平面的な）
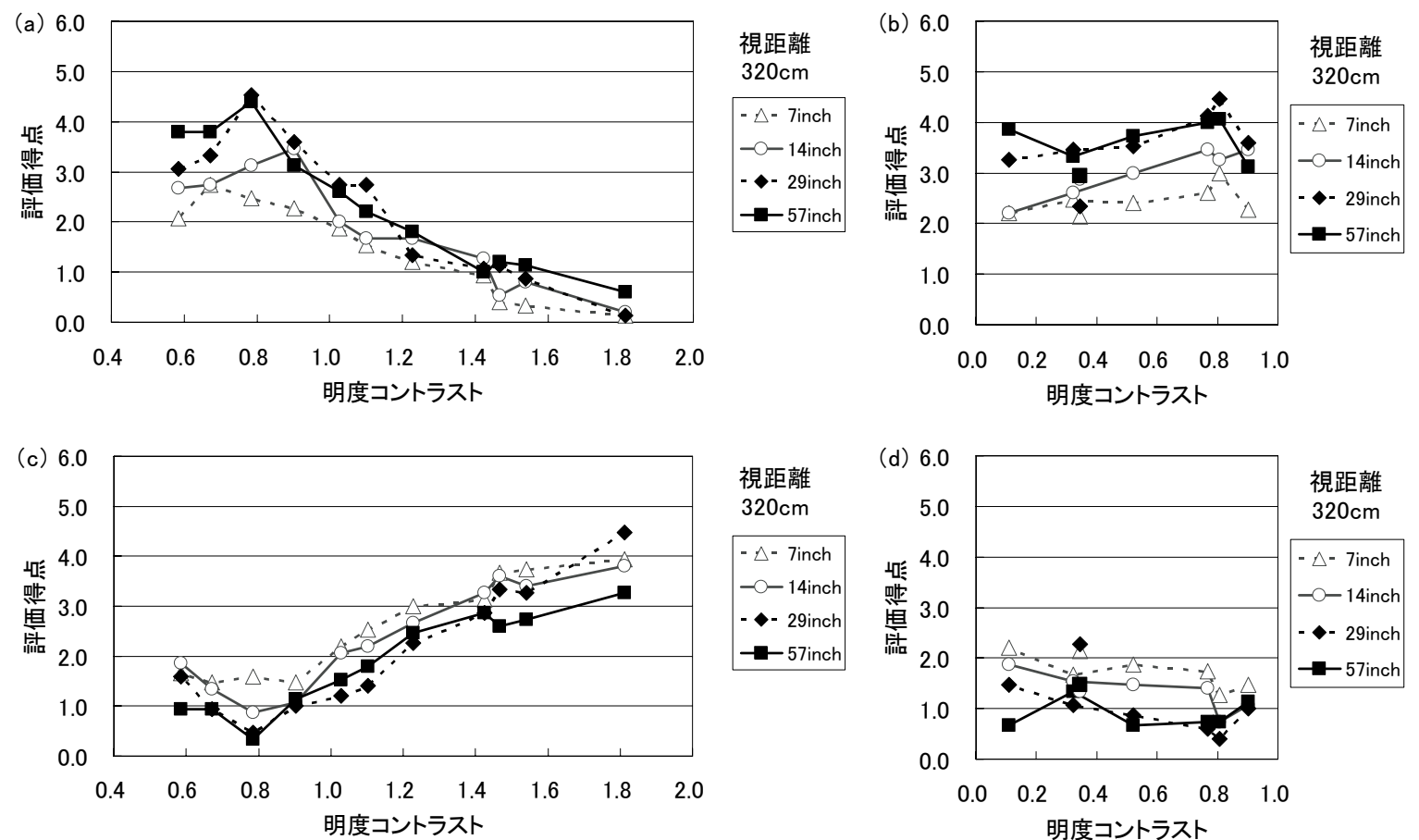

オブジェクト明度変化画像群

図8 評価得点と明度コントラストの関係（上：美味しそうな, 下：不味そうな）

画像サイズにも影響を受けることが明らかになった。

ここで注目すべきは，「美味しそうな」の評価得点におい て最大となる明度コントラスト（約 0.8 付近）が存在するこ とである。この傾向は, 感性的評価語である「きれいな」,「好 き」「自然な」の評価得点においても同様に見られた，これ ら4つの評価語（「美味しそうな」,「きれいな」，「好き」，「自 然な」) の評価得点結果は, どの組み合わせでも相関係数が
0.95 以上であった，分散分析の結果，「きれいな」，「好き」, 「自然な」の評価得点は，オブジェクト明度変化画像群にお いて，明度コントラスト及び画像サイズの影響は共に有意で あった $(\rho<0.01)$ 。したがって，これらの感性的評価語は何 らかの共通な画像属性を基に評価していると考えられ，その 一つが明度コントラストであり, 約 0.8 付近で評価が最大と なるといえる。しかしながら, 背景明度変化画像群において 
は若干傾向が異なり,「自然な」の評価得点では明度コント ラスト及び画像サイズの影響は共に有意であった $(\rho<0.01)$ が,「きれいな」,「好き」の評価得点は, 画像サイズの影響 が有意であるものの, 明度コントラストの影響に関しては有 意ではなかった。

以上より, 均一背景（背景明度：約 94）の中央に色鮮や かな果物オブジェクトが存在するような画像を撮影する場 合, 明度コントラスト $\left|L_{t}-L_{b}\right| / L_{a v}=$ 約 0.8 となるような照明 等の調整は,「美味しそうな」,「自然な」,「きれいな」,「好き」 等の感性的評価を向上させる一方法となり得ることが示され た。また,「美味しそうな」,「自然な」は, 背景明度が異な る場合に拈いても, 明度コントラスト＝約 0.8 とすることで, 高い評価が得られる可能性を示唆した。

\section{2 因子分析とその結果及び考察}

視距離の条件 2 種類の評価結果全体の傾向を調べるため, 視距離条件 2 種類各々における評価画像 68 種類（撮影画像 17 種類 $\times$ 画像サイズ 4 種類), すなわち, 合計 136 種類での 評価結果（被験者 15 名の平均値）を用いて因子分析を行っ た. 主因子法による因子抽出後はVARIMAX回転を行った。 その結果, 固有值 1 以上, 累積寄与率 $80 \%$ 以上を条件として, $3 つ の$ 因子が抽出された。 固有值, 寄与率, 累積寄与率の結 果を表3に, 各因子に㧍ける因子負荷量の結果を表4に示す。

表4より,殆どの評価語が第 1 因子に偏る結果となった。「派 手な」,「きれいな」等の感性的評価語が第 1 因子に多く存在 することから第 1 因子を感性的因子とする. この場合は肯定 的な評価語が負の值に, 否定的な評価語が正の值になってい る。また「色が薄い」，「明暗が弱い」等のコントラストに関 連する評価語が存在することから第 2 因子をコントラスト因 子とし, 最後に「平凡な」,「不自然な」で構成されることか ら第3因子を平凡性因子とした。また各因子の因子得点に関 する要因を検討するために, 重回帰分析を行った，以下では， その結果も踏まえて議論する。 ここで第 1 因子の因子得点と 明度コントラストとの関係を（a）オブジェクト明度変化画 像群と（b）背景明度変化画像群に分けて, 視距離 $160 \mathrm{~cm} の$ 場合を図 9 に, 視距離 $320 \mathrm{~cm}$ の場合を図10に示す。（なお撮 影画像17の因子得点は図の見易さからプロットのみで示す).

図9（a）と図10（a）ょり，オブジェクト明度变化画像 群においてはどちらの視距離でも, 明度コントラスト増加に 伴い, 因子得点が単調増加する傾向にある. 前述したように, 第 1 因子では肯定的評価語がマイナスの因子負荷量を示して いる. したがって, 因子得点増加に伴い, 特に負から正にな る点, すなわち, ゼロクロス点では肯定的から否定的な感性 的評価語の特性が強くなることを表し, 逆に得点減少は評価 が肯定的になることを意味する，ここでゼロクロス点に注目 すると, 図9（a）より, 視距離 $160 \mathrm{~cm}$ の 57inchの場合では, ゼロクロス点は明度コントラスト約 1.2 付近で生じており, 他のサイズに比べて高いことがわかる，また，低い明度コン トラストに扔ける因子得点は, 他のサイズに比べて低い, す なわち評価が高いことがわかる。,一方, 図10（a）ょり, 視
距離 $320 \mathrm{~cm}$ の場合は画像サイズによらずに明度コントラス トの約 0.9 付近において集中して負から正となっていること が分かる. 以上より, 視距離 $160 \mathrm{~cm}$ の 57 inchは, 他の条件 に比して，低い明度コントラストから高い明度コントラスト $\left(\left|L_{t}-L_{b}\right| / L_{a v}=\right.$ 約 1.2 付近）までのある程度の範囲で良い評価 が得られるとえよう。

これに対して, 図9（b）と図10（b）に示す背景明度変 化画像群では明度コントラスト増加に対して殆ど変化が無 い.これらから, 感性的因子はオブジェクト明度の変化によ り強く影響される。また背景明度変化画像群の結果では, オ ブジェクト明度変化画像群に比して，画像サイズの影響がよ り明確に見られる。図9（b）ょり，視距離 $160 \mathrm{~cm}$ の $57 \mathrm{inch}$ の結果では全ての明度コントラストにおいて因子得点が “-1”以下となっており，肯定的評価が非常に高いことを示 している.一方, 図 10 (b) より, 視距離 $320 \mathrm{~cm}$ の 7 inchの 結果ではプラスの因子得点が多く，否定的評価が多いことが 示されている.

以上を踏まえて感性的因子の因子得点を目的変数, オブ

表3 因子抽出結果

\begin{tabular}{|c|r|r|c|}
\hline 固有値番号 & 固有值 & 寄与率 & 累積寄与率 \\
\hline $\mathbf{1}$ & $\mathbf{1 3 . 8 0}$ & $\mathbf{6 2 . 7 3}$ & $\mathbf{6 2 . 7 3}$ \\
\hline $\mathbf{2}$ & 4.06 & $\mathbf{1 8 . 4 6}$ & $\mathbf{8 1 . 1 9}$ \\
\hline 3 & $\mathbf{1 . 6 5}$ & $\mathbf{7 . 4 9}$ & $\mathbf{8 8 . 6 8}$ \\
\hline 4 & 0.65 & 2.93 & 91.61 \\
\hline 5 & 0.39 & 1.77 & 93.39 \\
\hline
\end{tabular}

\section{表4 因子負荷量}

\begin{tabular}{|c|c|c|c|}
\hline 評価語 & 第1因子 & 第2因子 & 第3因子 \\
\hline 派手な & -0.95 & 0.21 & -0.04 \\
\hline きれいな & -0.94 & 0.12 & 0.25 \\
\hline 好き & -0.91 & -0.04 & 0.33 \\
\hline 美味しそうな & -0.90 & 0.04 & 0.38 \\
\hline はっきりした & -0.90 & -0.26 & 0.27 \\
\hline 地味な & $\mathbf{0 . 8 8}$ & -0.37 & -0.06 \\
\hline 印象的な & -0.87 & -0.21 & -0.18 \\
\hline 嫌い & $\mathbf{0 . 8 6}$ & -0.03 & -0.40 \\
\hline 不味そうな & $\mathbf{0 . 8 6}$ & -0.12 & -0.41 \\
\hline 污い & $\mathbf{0 . 8 2}$ & -0.30 & -0.38 \\
\hline 暗い & $\mathbf{0 . 8 0}$ & -0.52 & -0.25 \\
\hline 明るい & -0.78 & 0.59 & 0.06 \\
\hline ぼんやりした & $\mathbf{0 . 7 7}$ & 0.46 & -0.27 \\
\hline 立体的な & -0.76 & -0.29 & 0.40 \\
\hline 自然な & -0.74 & -0.04 & 0.61 \\
\hline 平面的な & $\mathbf{0 . 5 8}$ & 0.35 & -0.43 \\
\hline 明暗が強い & $\mathbf{0 . 5 7}$ & -0.54 & -0.31 \\
\hline 色が薄い & -0.12 & $\mathbf{0 . 9 2}$ & -0.15 \\
\hline 色が濃い & -0.14 & -0.82 & -0.21 \\
\hline 明暗が弱い & 0.02 & $\mathbf{0 . 7 9}$ & -0.11 \\
\hline 平凡な & -0.09 & 0.05 & $\mathbf{0 . 7 8}$ \\
\hline 不自然な & 0.65 & 0.07 & -0.72 \\
\hline & & & \\
\hline & & & \\
\hline
\end{tabular}


ジェクト明度と画像サイズを説明変数として重回帰分析を 行った結果, 重相関係数で 0.84 を得た。オブジェクト明度, 画像サイズの標準偏回帰係数は各々 $-0.80,-0.28$ である。す なわち, 感性的因子にはオブジェクト明度と画像サイズが寄 与し, 特に前者の影響が強いことが示された. 因子分析によ る因子得点と重回帰式による推定值の相関図を図11に示 す。なお，実線は重回帰直線である。

また，図 $12 に$ 視距離 $320 \mathrm{~cm}$ における明度コントラストに 対する第2因子の因子得点を示す. 図12 (a)より, オブジェ クト明度変化画像群においては, 明度コントラストの増加に 伴い, 因子得点は単調減少傾向にある. 第 2 因子では第 1 因 子と同様に, マイナス方向で因子得点の絶対值が高くなるに
つれて, コントラスト関連の評価がプラスになると解釈され る.ここでゼロクロス点に注目すると, 画像サイズが小さい 場合は比較的高い明度コントラストにおいて正から負へ, 画 像サイズが大きい場合は比較的低い明度コントラストにおい て正から負へと変化している。 したがって，コントラスト因 子はサイズが小さい画像に対しては高い明度コントラストま で悪い評価となり，逆にサイズが大きい画像は，比較的低い 明度コントラストにおいて良い評価になることを示してい る.これに対し, 図12 (b) に示吉背景明度変化画像群では, 明度コントラスト増加に伴い, 因子得点は単調増加する傾向 にある．ゼロクロス点は画像サイズが小さい場合は，比較的 低い明度コントラストに拈いて負から正への変化が生じてい

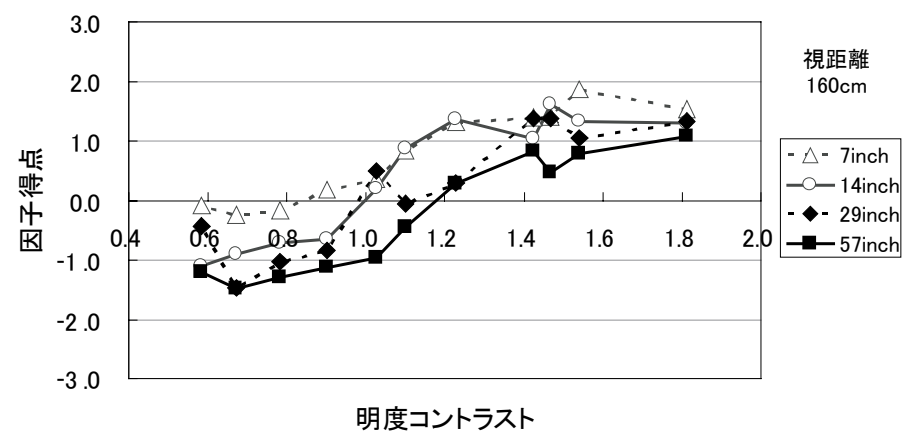

（a）オブジェクト明度変化画像群

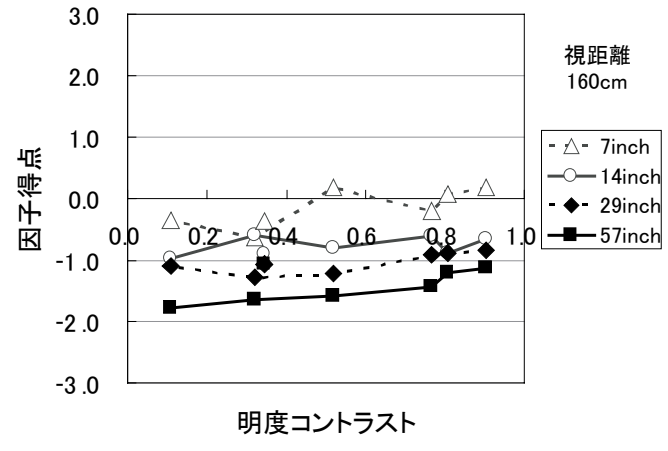

(b) 背景明度変化画像群

図9 感性的因子の因子得点と明度コントラストとの関係（視距離 $160 \mathrm{~cm}$ ）

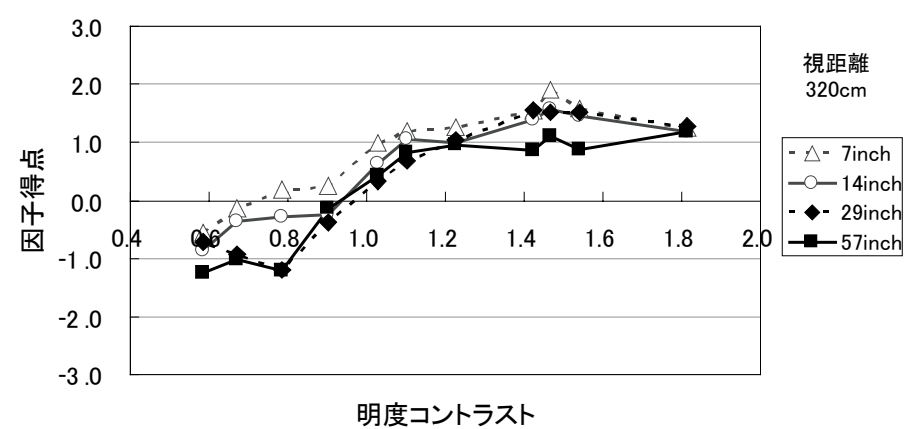

（a）オブジェクト明度変化画像群

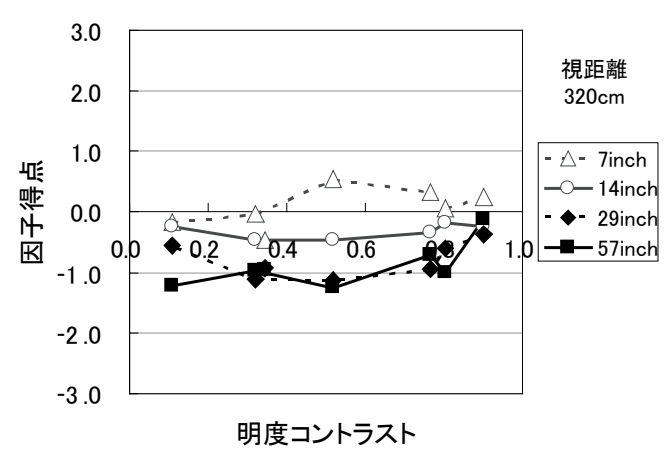

(b) 背景明度変化画像群

図 10 感性的因子の因子得点と明度コントラストとの関係（視距離 $320 \mathrm{~cm}$ )

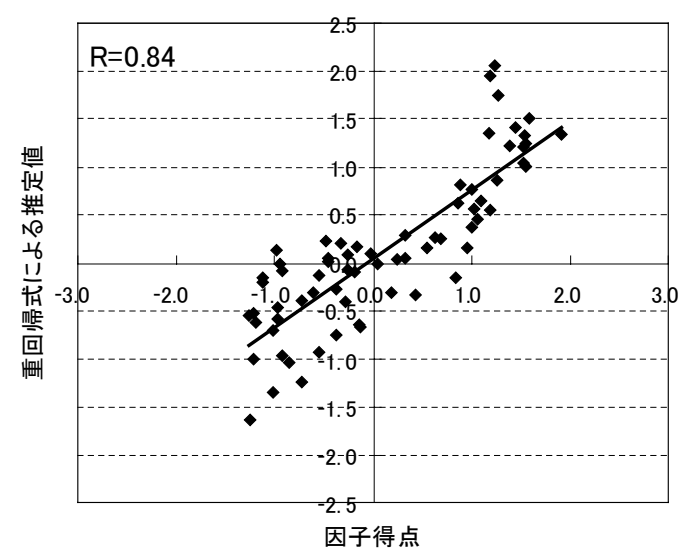

図11 重回帰分析の結果（目的変数：因子得点, 説明変数 : オブジェクト明度, 画像サイズ) 


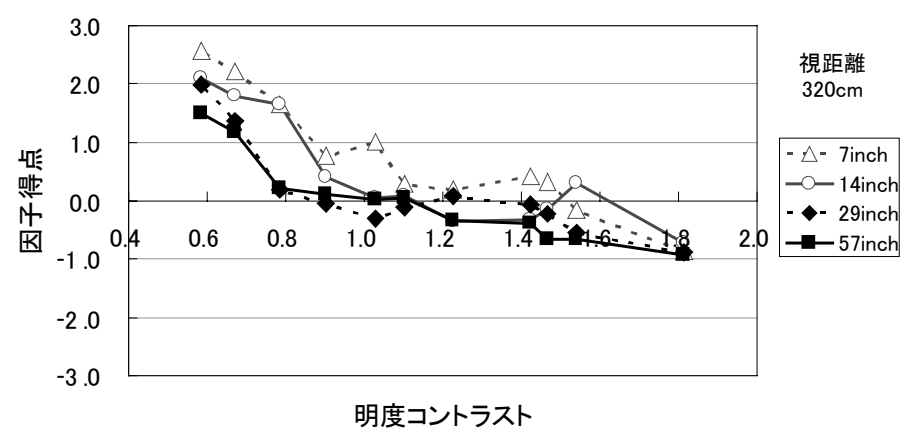

(a) オブジェクト明度変化画像群

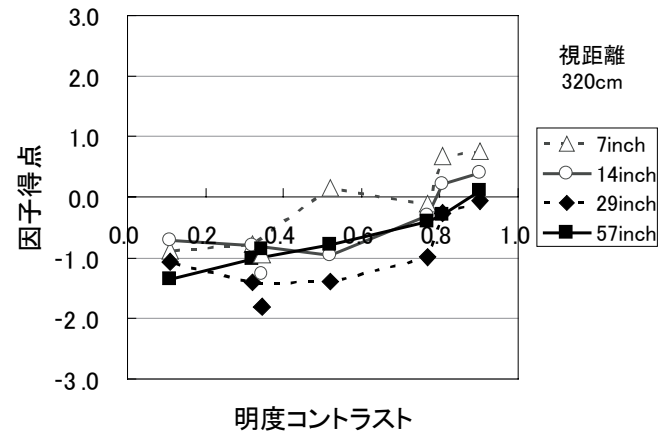

(b) 背景明度変化画像群

図 12 コントラスト因子の因子得点と明度コントラストとの関係（視距離 $320 \mathrm{~cm} ）$

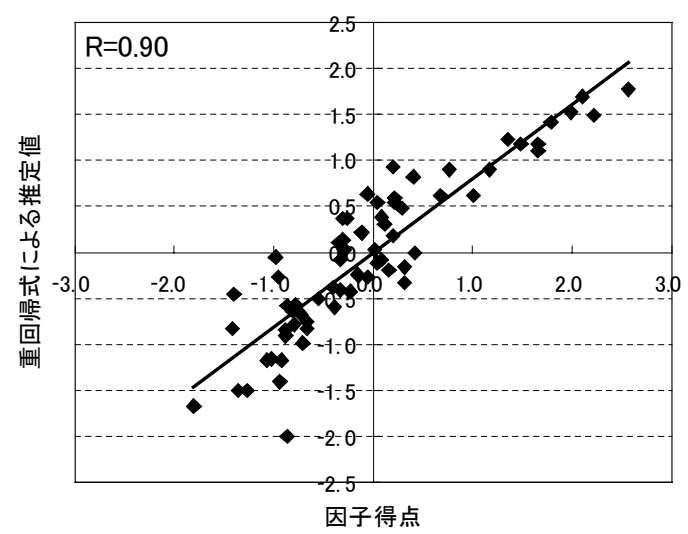

図 13 重回帰分析の結果（目的変数：因子得点, 説明変数：画像全体の明度の平均值, 標準偏差, 画像サイズ）

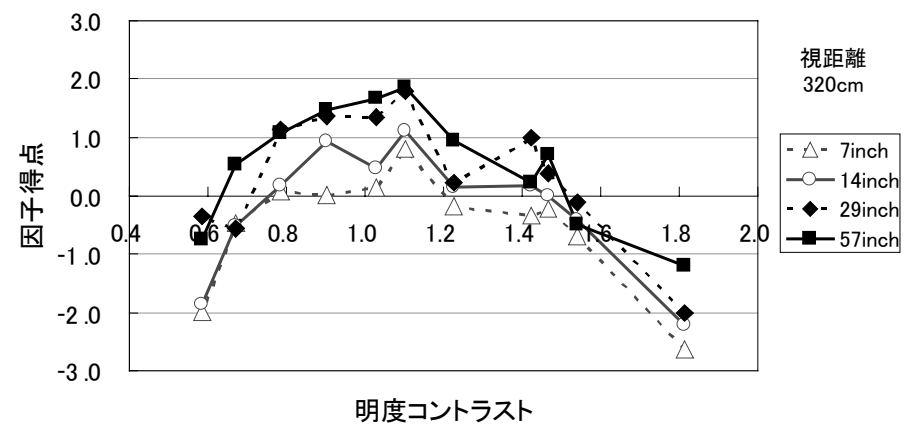

（a）オブジェクト明度変化画像群

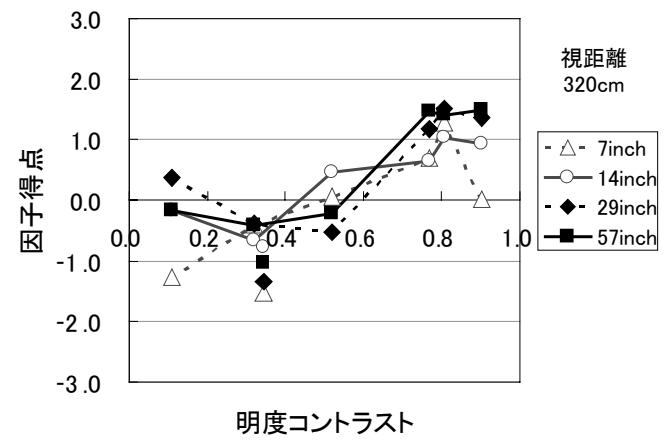

(b) 背景明度変化画像群

図 14 平凡性因子の因子得点と明度コントラストとの関係（視距離 $320 \mathrm{~cm}$ ）

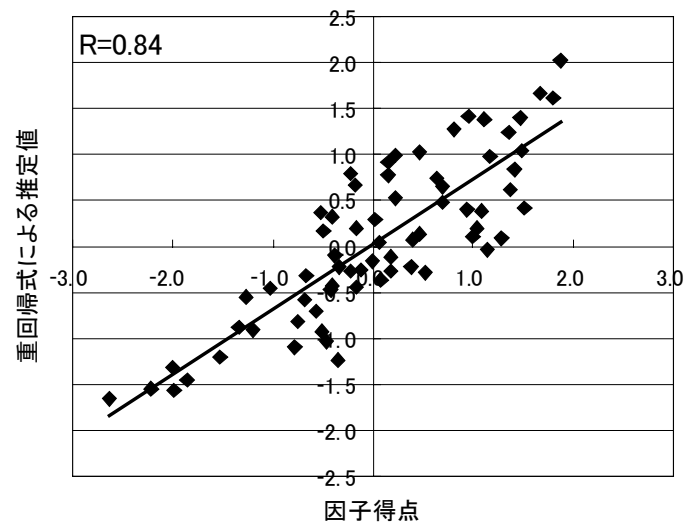

図 15 重回帰分析の結果（目的変数：因子得点, 説明变数 : 画像サイズ, $\left|L_{t}-L_{6}\right| L_{b}$ ) 
るのに対し，画像サイズが大きい場合は，ある程度の明度コ ントラストがないと負から正にならない。オブジェクト明度 変化画像群の結果と総合して考えると, コントラスト因子は 画像サイズに影響される結果であるといえる。また, 図12 （a）（b）ょり，第2因子の因子得点は本研究での明度コント ラスト $\left|L_{t}-L_{b}\right| / L_{a v}$ の単純な関数ではない. 図12(a)(b) で因子得点が最も低い，すなわち，コントラスト関連の評価 が最も高いのは，各々条件(1)と条件17で，これらに共通する のは, オブジェクト又は背景が暗いので, 画像全体の平均明 度が低くなっていることと, 明るい部分と暗い部分の差が大 きい,すなわち, 明暗のばらつきが大きいということである. 以上を踏まえて, コントラスト因子の因子得点を目的変数, 画像全体の明度の平均值, 標準偏差, そして画像サイズを説 明変数として重回帰分析を行った結果, 重相関係数で 0.90 を得た. 各々の標準偏回帰係数は, 画像全体の明度の平均值： 0.97, 標準偏差:-0.29, 画像サイズ:-0.24である. すなわち, コントラスト因子には画像全体の明度の平均值, 標準偏差, そして画像サイズが関連し, 特に, 画像全体の明度平均值の 影響が強いことが示された. 第2 因子の因子得点と重回帰式 による推定值の相関図を図13に示す。実線は重回帰直線で ある。

最後に, 図 14 に視距離 $320 \mathrm{~cm}$ における明度コントラスト に対する第 3 因子の因子得点を示す。図14(a)より,オブジェ クト明度変化画像群においては明度コントラスト増加に伴 い, 因子得点は最大值を持つ傾向にある．特に明度コントラ スト 1.10 （すなわち, オブジェクト明度 $L_{6}=27.40 ）$ 付近に おいて顕著に現れており, 画像サイズによる因子得点の違い も見られる．また第 3 因子は「平凡な」がプラスの因子負荷 量を示しているため, 因子得点がプラスになるにつれて平凡 性関連の評価がプラスになると解釈される。また図14（b） より, 背景明度変化画像群では明度コントラスト増加に伴 い, 因子得点は段階的な増加傾向にある. 以上を踏まえて平 凡性因子の因子得点を目的変数, 画像サイズと $\left|L_{t}-L_{6}\right| / L_{b}$ を 説明変数として重回帰分析を行った結果, 重相関係数で 0.84 を得た。各々の標準偏回帰係数は画像サイズ：-0.80, $\left|L_{t}-L_{6}\right| / L_{b}: 0.28$ である. すなわち, 平凡性因子には画像サイ ズと $\left|L_{t}-L_{6}\right| / L_{b}$ が関連し, 特に画像サイズの影響が大きいこ とが示された，因子得点と重回帰式による推定值の相関図を 図15に示す。なお実線は重回帰直線である。

\section{4. 他の関連研究との比較}

色彩画像の感性的評価に関する先行研究 $[6,8]$ において, 感性的評価がオブジェクトと背景の明度コントラストにより 変化することや，画像サイズにより変化することを明らかに してきた，本実験においてもそれと矛盾がない結果を得てい る. また新たに得られた結果としては, 特定の評価語に対し ては, 適切な明度コントラスト $\left(\left|L_{t}-L_{b}\right| / L_{a v}=\right.$ 約 0.8) の存 在が示唆されたことである。この点については得られた明度 コントラストが他の表示デバイスを用いた場合でも同様の結
果が得られるかどうか等の観点からより詳しく検討する必要 がある、

また画像の印象評価に対する画面サイズや視距離の影響を 検討した研究は多いので, 以下に代表的なものを紹介し, 本 実験の結果と比較・検討する.

成田ら $[9,10]$ は，ポストハイビジョンとして超高精細・ 大画面テレビ (UDW : Ultra high-Definition and Wide-screen Television）の可能性を検討した。評価実験は人物, 風景, 室内等を撮影したスライドフィルムをプロジェクタにより透 過型スクリーン $($ 幅 $368 \mathrm{~cm} \times$ 高さ $277 \mathrm{~cm})$ に投影して行った。 表示サイズは 4 種類（60～150inch）とした．約 15 名の被験 者はスクリーン提示画像を観察して最も好ましい鑑賞位置を 回答した。そその結果, 画面サイズに対する好ましい観視距離 $\mathrm{d}(\mathrm{cm})$ は画面幅 $\mathrm{w}(\mathrm{cm})$ の関数 $(\mathrm{d}=0.6 \mathrm{w}+41)$ で示される とした.ここで, 本評価実験での最大画像サイズ (57inch) から，好ましい観視距離を上式により計算すると約 $126 \mathrm{~cm}$ と なる、したがって，画像サイズ 57 inchで視距離 $160 \mathrm{~cm}$ の場 合の評価が他の条件に比して高い理由は, 視距離 $160 \mathrm{~cm}$ が好 ましい観視距離に比較的近かったからではないかと推測され

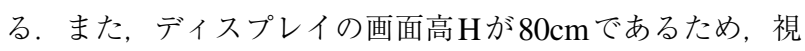
距離 $160 \mathrm{~cm}$ は $2 \mathrm{H}$ に相当する. 八イビジョンの推奨観視距離 は3Hであるが，それよりも近距離の方が高い評価を得た。 成田らの研究 [9] でも同様の傾向であった，すなわち，大 画面ディスプレイで, 感性的評価をより高めるためには, $3 \mathrm{H} よ り も 2 \mathrm{H}$ 程度で観察する方が良いことが示唆された。

また, 畑田ら [11]は広視野効果を定量的に求めるために, 方向感覚誘導効果の実験を行った。具体的には, 半球面スク リーン内に円状に投影された表示映像における物体の傾き や動きにより，それを直立姿勢で観察する被験者に生じる重 心移動を計測して, 臨場感知覚の程度を推定した。 その結

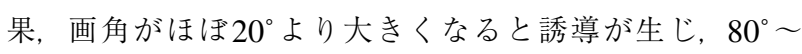
$100^{\circ}$ 以上で飽和状態になるという結果を示した。 また，畑 田の解説 [12］に扔いても，画像を見込む角度が $30^{\circ}$ 以上か ら迫力のある画面サイズになると述べられている。本実験に おいて水平方向の画角が $20^{\circ}$ 以上になる条件は, 視距離 $160 \mathrm{~cm}$ の 29inch $\left(21.4^{\circ}\right)$ と57inch $\left(41.4^{\circ}\right)$ 及び視距離 $320 \mathrm{~cm}$ の 57inch $\left(21.4^{\circ}\right)$ である. したがって, これらの条 件における感性的評価が他の条件に比べて高かったのは，十 分な臨場感が得られる画角条件を満たしていたことが一因 と考えられる.

\section{5. お わり に}

本研究では, 画像内のオブジェクトと背景の明度コントラ ストが異なる 17 種類の画像を撮影し, 撮影画像のサイズを 4 種類に変換処理した合計 68 枚を評価画像とした。 そしてそ れらを用いて，2種類の視距離から感性的評価実験を行い, その結果から, 明度コントラストや画像表示サイズ等と感性 的評価との関係を調べた。評価得点と明度コントラストや画 像サイズとの関係, 及び二元配置分散分析の結果から, 評価 
語群が傾向別に3 種類に分類されることが明らかになった

・第 1 群：明度コントラストに強い影響を受けるが, 画像サ イズにはあまり影響を受けない評価語群（「明る い」「暗い」など）

・第2群：画像サイズに強い影響を受けるが, 明度コントラ ストにはあまり影響を受けない評価語群（「立体 的な」「平面的な」など）

・第3 群：明度コントラスト及び画像サイズの双方に影響を 受け, 且つ特定の明度コントラスト $\left(\left|L_{t}-L_{b}\right| / L_{a v}\right.$ $=$ 約 0.8 ) で評価得点の最大值・最小值を持つ感性 的評価語群（「美味しそうな」「不味そうな」など）

ここで表1より，本研究で得られた結果である第3群にお ける特定の明度コントラスト（撮影画像(9)）をオブジェクト 明度と背景明度の比 $\left(L_{t} / L_{b}\right)$ で表すと約 0.44 となる。すな わち, 画面中央に果物等のオブジェクトが存在し, 均一背景 （背景明度：約94）を持つような画像コンテンツの作成にお いて,「美味しそうな」,「きれいな」,「好き」,「自然な」等 の感性的評価を高めるための一つの方法として,「オブジェ クトの明るさ：背景の明るさ」が「2：5」となるように照 明して撮影すれば良いことが示唆された。

また，因子分析により 3 つ因子：感性的因子, コントラ ス卜因子, 平凡性因子が抽出され, 更に重回帰分析の結果か ら, 各々に寄与する要因が推定された。

・感性的因子：オブジェクト明度と画像サイズが強く関係し ている．特に視距離 $160 \mathrm{~cm}$ の $57 \mathrm{inch} は$ 低い明度コントラ ストから高い明度コントラストまで, ある程度の範囲にお いて良い評価を得ることができ, 他の条件に比して評価が 高いことが示された。

・コントラスト因子：画像全体の明度の平均值, 及び標準偏 差及び画像サイズが強く関係している.

・平凡性因子：画像サイズ, 及びオブジェクト明度と背景明 度の比からの特定のずれ $\left|L_{t}-L_{6}\right| / L_{b}$ が強く関係している.

今回は表示媒体の影響を避けるため, 一種類の表示ディス プレイ（液晶）だけを用いて画像を表示させたが, 表示媒体 の違いによる評価への影響を検討するためには, 他の媒体 (PDP, 有機EL等) を用いて実験を行う必要がある [13]. 更に, 使用する画像コンテンツの種類を増加させ, 一般性を 高めること等により, 異なる撮影条件や視環境における等価 的で安定した感性的価值を与えうる画像提示手法の確立が期 待される.

\section{参 考 文 献}

１］平成 20 年版情報通信白書（総務省）, http://www.soumu.go.jp/johotsusintokei/whitepaper/ja/ h20/index.html

[2] Matt Jones, Gary Marsden, Norliza Mohd-Nasir, Kevin Boone, George Buchanan: “Improving Web Interaction on Small Displays", Computer Networks 31, pp.1129-1137 (1999).
[3] Robert L. Duchnicky, Paul A. Kolers: "Readability of Text Scrolled on Visual Display Terminals as a Function of Window Size", Human Factors, Vol.25, No.6, pp.683-692 (1983).

[4] Minhee Chae,Jinwoo Kim: "Do size and structure matter to mobile users? An empirical study of the effects of screen size, information structure, and task complexity on user activities with standard web phones", Behaviour \& Information Technology, Vol.23, No.3, pp.165-181 (2004).

［5］菅原正幸：“走查線 4000 本級超高精細映像システム”, 映 像情報メディア学会誌, Vol.57, No.11, pp.1442-1444 (2003).

６］阿山みよし, 白川俊之, 清水智弘, 小黒久史, 郭素梅, 佐 藤美恵, 江田哲也, 石川智治, 春日正男: “色彩画像の感 性的評価一画像サイズ, 明度および彩度コントラストの影 響一”, 感性工学, Vol.9, No.2, pp.177-187 (2010).

[7] 郭素梅, 小黑久史, 佐藤美恵, 阿山みよし, 春日正男：“映 像コンテンツの感性評価における単極評価法の有効性に関 する検討”, 感性工学, Vol.8, No.4, pp.1091-1098（2009）.

[8] 小黒久史, 郭素梅, 清水智広, 佐藤美恵, 春日正男, 阿山 みよし：“感性的評価に基づく画像の色演出と評価構造の 画面サイズ依存性の検討”, 画像電子学会誌, Vol.35, No.5, pp.528-537 (2006).

[9］成田長人, 金澤勝, 岡野文男：“超高精細 ·大画面映像の 鑑賞に適した画像サイズと観視距離に関する考察”，映像 情報メディア学会誌, Vol.55, No.5, pp.773-780（2001）.

[10］成田長人, 金澤勝, 岡野文男: “超高精細 - 大画面映像シ ステムの画面パラメータ - 静止映像による画面縦横比と 最大画素数の検討 - ”, 映像情報メディア学会誌, Vol.56, No.3, pp.437-446 (2002).

[11] 畑田豊彦, 坂田晴夫, 日下秀夫：“画面サイズによる方向 感覚誘導効果 - 大画面による臨場感の基礎知識 - ”, テレ ビジョン学会誌, Vol.33, No.5, pp.407-413 (1979).

[12］畑田豊彦：“総説：高臨場感を生み出す大画面ディスプレ イ効果”, 映像情報メディア学会誌, Vol.56, No.8, pp.1213-1215 (2002).

[13］小黒久史, 郭素梅, 鈴木直哉, 佐藤美恵, 阿山みよし, 春 日正男：“カメラワークによる感性的効果の表示デバイス 依存性に関する検討”, 感性工学, Vol.7, No.4, pp.821-830 (2008).

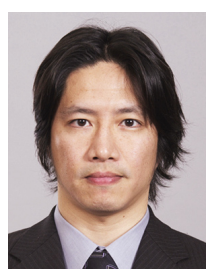

\section{石川 智治 (正会員)}

1997 年, 北陸先端科学技術大学院大学 情報 科学研究科博士前期課程了. 2001 年, 同大 学 情報科学研究科 博士後期課程了. 同年, 日本学術振興会未来開拓学術研究推進事業 RA，北陸先端大情報 助手を経て，2008年 より, 宇都宮大学大学院 工学研究科 助教. 人間の認知 - 感性を 考慮した「場」の実現に関する研究に従事. 博士 (情報科学). 


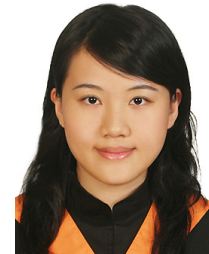

陳 怡君（非会員）

2009 年, 台湾国立台湾師範大学グラフィッ クコミュニケーション学科印刷科技専攻修 士課程修了。同年 10 月より, 宇都宮大学工 学研究科システム創成工学専攻 博士後期課 程. 色彩工学に関する研究に従事.

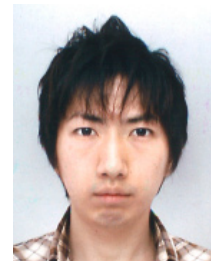

\section{白川 俊之（非会員）}

2007年, 宇都宮大学工学部情報工学科卒業. 2009 年, 宇都宮大学工学研究科情報制御シ ステム科学専攻 博士前期課程 修了. 色彩画 像の感性的評価に関する研究に従事.

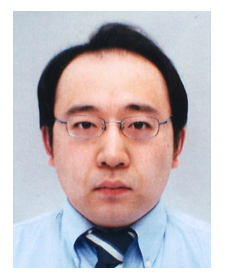

江田 哲也（正会員）

2006 年宇都宮大学大学院工学研究科情報制 御システム科学専攻博士後期課程修了. 博士 (工学). 現在, 国際医療福祉大学情報教育セ ンター, 研究・技術補助員。医療情報教育に 関する研究に従事. 日本感性工学会, 照明学会, 日本色彩学会, 日本医療情報学会 各会員.

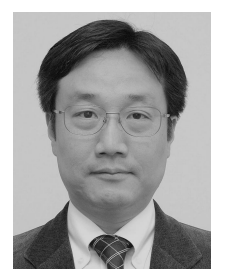

小黒 久史 (非会員)

凸版印刷 (株) 総合研究所 情報技術研究所 主 席研究員. 1984 年千葉大学工学部画像工学 科卒業. 凸版印刷 (株) 入社. 図形/画像処理, インターネットなどに関する研究開発に従 事. 1997 年から高精細バーチャルリアリティを用いた文化資産 の保存活用のための研究開発に携わる. 現在, 総合研究所情報 技術研究所にて, 感性的評価を応用したコンテンツの表現品質 向上技術の実現に取り組む. 博士 (工学). 宇都宮大学大学院客 員教授.

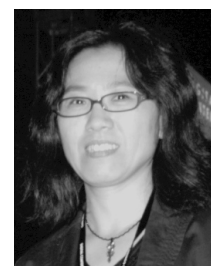

郭 素梅 (非会員)

中国北京理工大学珠海学院教授. 1983 年 7 月 中国太原工学院電子工学科卒業. 1986年6月 華中工学院大学院修士課程修了。同年 7 月北 京理工大学電子工学科. 助教を経て同専任講 師. 1998 年 3 月慶應義塾大学大学院電気工学専攻博士後期課程 修了, 博士 (工学)。同年 4 月凸版印刷株式会社入社. 総合研究 所情報技術研究所にて, 印刷に対応した画像電子透かし, 映像 の感性評価に関する研究開発に携わる。 2010 年 3 月より現職, 画像処理の研究と教育に従事. 画像電子学会会員.

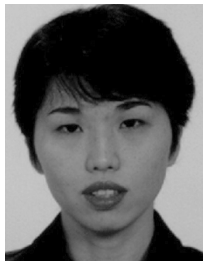

\section{佐藤 美恵（正会員）}

2001 年 3 月, 東京工業大学大学院情報理工学 研究科計算工学専攻博士後期課程修了. 博士 (工学)。同年 4 月, 日本学術振興会特定国派 遣研究者としてスイス連邦工科大学チューリ 七校客員研究員。2002年3月，宇都宮大学工 学部助手. 2008 年 3 月, 同大大学院工学研究科准教授. 現在に 至る。画像処理, 感性情報処理, ヒューマンインタフェース, 映像提示技術に関する研究に従事.

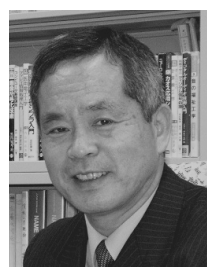

春日 正男 (正会員)

1971 年名古屋大学大学院工学研究科修了. 現在, 宇都宮大学大学院工学研究科教授. 研 究分野：感性情報処理, 高度情報通信におけ る知的情報処理, マルチメディア情報処理, 人間工学における生態情報処理, 及びそれら の福祉，医学への応用に関する研究に関心を持つ.

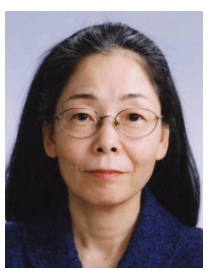

阿山 みよし（正会員）

1983 年東工大 · 総合理工 · 物理情報工学専 攻修了。ヨーク大学, 東工大, 東京都神経研 を経て, 1993 年宇都宮大学工学部助教授. 2001 年より同学部教授. 現在は大学院工学 研究科学際研究部門教授およびオプティクス 教育研究センター副センター長. 工博. 視覚・色彩科学の研究 と教育に従事. 